\title{
Formulasi Komposisi Membran Kitosan dan Optimasi Pengadukan dalam Penurunan Kandungan Padatan Limbah Cair Kelapa Sawit
}

\author{
Formulation of Chitosan MEMbrane Composition and Stirring \\ Optimization for Reducing Total Solid of Palm OIL Mill EFfluent
}

Sri Wahyuni ${ }^{1, *}$, Siswanto ${ }^{1}$, dan Soekarno Mismana Putra ${ }^{1}$

${ }^{1}$ Pusat Penelitian Bioteknologi dan Bioindustri Indonesia, PT. Riset Perkebunan Nusantara, Bogor 16128, Indonesia

${ }^{*}$ E-mail: sri09wahyuni@gmail.com

\begin{tabular}{|c|c|}
\hline ARTICLE INFO & Abstract \\
\hline $\begin{array}{l}\text { Article history } \\
\text { Received date: } \\
17 \text { November } 2016 \\
\text { Received in revised form date: } \\
6 \text { January } 2017 \\
\text { Accepted date: } \\
18 \text { January } 2017 \\
\text { Available online date: } \\
31 \text { May } 2017\end{array}$ & $\begin{array}{l}\text { Palm oil mill effluent (POME) is palm oil industry wastewater with } \\
\text { high solid content. Waste filtration using chitosan membrane has } \\
\text { been investigated to decrease the solid waste, but the final value have } \\
\text { not met the quality standards yet. Therefore, further development of } \\
\text { formulation and optimization of the membrane manufacturing pro- } \\
\text { cess (composition and stirring speed) are needed. The purpose of this } \\
\text { study was to determine the effect of composition and stirring speed on } \\
\text { the performance of the membrane in decreasing the solid content of } \\
\text { POME. Chitosan membrane was prepared by phase inversion method } \\
\text { with two supporting materials, namely Poly Ethylene Glycol (PEG) } \\
\text { and Poly Vinyl Alcohol (PVA). The variables of this experiment were } \\
\text { Chitosan: ratio PVA (40:60, } 45: 55,50: 50,55: 45 \text { and } 60: 40(v / v) \text { ) and } \\
\text { stirring speed (200 rpm and } 250 \text { rpm). Chitosan composite membrane } \\
\text { was tested in a cross flow reactor system. The result showed that the } \\
\text { highest rejection values of TSS and TDS generated by the membrane } \\
\text { on the chitosan and PVA ratio of 50:50 (v:v) at stirring speed of } 250 \\
\text { rpm were } 96.84 \% \text { and } 97.23 \% \text {, respectively. }\end{array}$ \\
\hline
\end{tabular}

Keywords: Chitosan membrane, POME, Solid rejection, TSS, TDS

Kata kunci:

Membran kitosan

POME

Penurunan padatan

TSS

TDS

\begin{abstract}
Abstrak
Limbah cair kelapa sawit (LCKS) atau yang lebih dikenal dengan $P O M E$ merupakan limbah cair industri kelapa sawit dengan kandungan padatan yang tinggi. Filtrasi limbah dengan menggunakan membran kitosan telah diteliti dapat menurunkan nilai padatan pada limbah POME, namun hasil filtrasi masih belum memenuhi baku mutu. Oleh karena itu, perlu dilakukan pengembangan kualitas membran dengan cara formulasi dan optimasi proses pembuatan membran (komposisi dan kecepatan pengadukan). Penelitian ini bertujuan untuk mengetahui pengaruh komposisi dan kecepatan pengadukan terhadap kinerja membran dalam penurunan nilai padatan POME. Membran kitosan dibuat dengan metode phase inversion dengan bahan pendukung Poli Etilene Glikol (PEG) dan Poli Vinil Alkohol (PVA). Komposisi yang diuji meliputi rasio kitosan: PVA (40:60, 45:55, 50:50, 55:45 dan 60:40 (v/v)) dan kecepatan pengadukan (200 rpm dan $250 \mathrm{rpm})$. Membran kitosan diujikan pada sistem reaktor cross flow. Hasil penelitian menunjukkan bahwa nilai penurunan TSS dan TDS tertinggi dihasilkan oleh membran pada rasio kitosan dan PVA 50:50 (v:v) pada kecepatan pengadukan $250 \mathrm{rpm}$ yaitu masing-masing sebesar $96,84 \%$ dan $97,23 \%$.
\end{abstract}




\section{PENDAHULUAN}

Pesatnya pertumbuhan industri minyak sawit di Indonesia selain memberikan dampak positif juga menimbulkan dampak negatif bagi masyarakat, khususnya limbah cair yang dihasilkan. Karakteristik kimia dari limbah cair kelapa sawit (LCKS) atau yang lebih sering kita kenal sebagai palm oil mill effluent (POME) memiliki nilai parameter yang jauh melebihi baku mutu limbah sawit yang ditetapkan, terutama nilai Total Suspended Solid (TSS) dan Total Dissolved Solid (TDS). Kadar TSS pada limbah POME mencapai 18.000-34.000 $\mathrm{mg} / \mathrm{L}$ (Rupani et al. 2016), nilai tersebut jauh dari baku mutu limbah cair kelapa sawit yang ditetapkan oleh pemerintah, yaitu sebesar 250 mg/L (PerMenLH 2014). Keberadaan limbah tersebut menjadi masalah bagi para pengelola industri kelapa sawit, sehingga perlu dikembangkan sistem pengolahan limbah cair kelapa sawit yang secara signifikan dapat mengurangi nilai kandungan padatan limbah POME.

Dalam aplikasi pengolahan limbah cair khususnya penurunan nilai padatan limbah, filtrasi membran menjadi alternatif teknologi karena efisiensi pemisahannya yang tinggi. Filtrasi membran merupakan teknik pemisahan dua atau lebih campuran tanpa menggunakan panas dan terpisah berdasarkan ukuran dan bentuknya dengan bantuan tekanan dan selaput semi-permeable (Setiawan, Argo, and Hendrawan 2015). Bahan baku serta proses pembuatan membran sangat memengaruhi kinerja filtrasi membran (Suseno, Adiarto, and Atie 2003). Salah satu bahan yang paling banyak digunakan sebagai bahan membran adalah kitosan. Selain memiliki kemampuan dalam membentuk film, pengolahan mudah,dan ketersediaan yang melimpah; sifat polikationik kitosan berperan penting pada proses pemisahan padatan dalam aplikasi filtrasi (Dash et al. 2011).
Sifat polikationik kitosan mendorong terjadinya proses adsorpsi dan absorpsi pada membran sehingga polutan tidak hanya tertahan di permukaan membran, polutan yang lolos dari permukan membran dan masuk ke dalam membran akan mengalami proses penyerapan kembali (absorpsi) oleh membran bagian dalam, sehingga polutan tetap tertahan didalam membran (Wahyuni 2016). Akan tetapi, sifat dasar kitosan yang rapuh dan hidroskopis masih menjadi kendala dalam aplikasi filtrasi, sehingga perlu dilakukan formulasi dan optimasi pada komposisi bahan dan proses pembuatan membran. Kitosan dapat dikombinasikan dengan Polyvynil Alcohol (PVA) dan Poly Ethylene Glikol (PEG) untuk membentuk membran kitosan yang hidrofobik dan kuat (Ariyaskul et al. 2006; Hyder and Chen 2009; Bolto et al. 2009; Zhu et al. 2010; Yu et al. 2011; Erizal et al. 2013; Salehi and Madaeni 2014). Gugus amina pada kitosan akan bereaksi dengan gugus $\mathrm{OH}$ - dari PVA melalui ikatan hidrogen sehingga akan memperkuat sifat komposit membran (Riyanto, Suwandi, dan Permana 2010; Lusiana, Siswanta, and Hayashita 2013). Pembentukan pori membran dan penyebarannya sangat menentukan kinerja membran. PEG sebagai template pori yang ditambahkan ke dalam komposit membran berperan dalam penyeragaman dan pemerataan distribusi pori membran (Salehi and Madaeni 2014; Mahatmanti, Nuryono, and Narsito 2016; Mahatmanti, Nuryono, and Narsito 2017).

Membran kitosan yang termodifikasi dengan PVA dan PEG telah terbukti efektif dalam pengolahan limbah industri (Yunarsih, Manurung, and Putra 2013; Hidayat 2014a; Hidayat 2014b). Walaupun pemanfaatan PVA dan PEG dalam pembuatan membran sudah dilaporkan, tetapi perlu dilakukan pengembangan kualitas membran dengan cara optimasi proses 
pembuatan membran (rasio komposisi dan kecepatan pengadukan).

Penelitian ini dilakukan untuk mengetahui formulasi komposisi membran kitosan dan optimasi kecepatan pengadukan optimum serta pengujian dalam penurunan nilai padatan limbah cair kelapa sawit. Hasil penelitian diharapkan dapat menjadi alternatif pengolahan limbah POME dalam penurunan total padatan, sehingga dapat mengurangi beban pengolahan lanjutan pada alur pengolahan limbah cair kelapa sawit.

\section{METODE}

\section{Sintesis Kitosan}

Kitosan yang digunakan dalam penelitian ini berasal dari limbah rajungan yang diperoleh dari PT. Kelola Mina Laut, Gresik. Proses sintesis kitosan dilakukan melalui tiga tahap, yaitu demineralisasi, deproteinasi, dan deasetilasi (Asni, Saadilah, and Saleh 2014). Tahap deproteinasi dilakukan dengan menggunakan larutan $\mathrm{NaOH} 3 \%$ dengan perbandingan kitosan dan $\mathrm{NaOH}$ sebesar 1:7 (b/v) pada suhu $100{ }^{\circ} \mathrm{C}$ selama satu jam. Tahap demineralisasi dilakukan dengan menggunakan HCL $3 \mathrm{~N}$ dengan perbandingan 1:10 (b/v) pada suhu kamar $\left(30{ }^{\circ} \mathrm{C}\right)$ selama empat jam. Proses deasetilasi dilakukan dengan menggunakan larutan $\mathrm{NaOH} 50 \%$ pada suhu $135^{\circ} \mathrm{C}$ selama satu jam. Kemudian disaring dengan menggunakan kertas saring dan residu berupa kitosan dicuci menggunakan aquades hingga $\mathrm{PH}$ air pencuci netral, kitosan yang diperoleh kemudian dikeringkan pada suhu $60{ }^{\circ} \mathrm{C}$ selama 48 jam.

\section{Karakterisasi Kitosan}

Karakterisasi kitosan meliputi penentuan bau, warna, kelarutan, kadar air, kadar abu, viskositas, dan pengukuran derajat deasetilasi (DD). Pengujian warna dan bau dilakukan secara organoleptik. Pengujian kelarutan kitosan dilakukan dengan pelarutan dalam $20 \mathrm{ml}$ asam asetat 1,5\%. Pengujian viskositas dilakukan dengan menggunakan viskometer Brookfield seri DV-E spindle RV3. Pengujian kadar air dan kadar abu dilakukan dengan metode gravimetri (APHA, AWWA and WEF 2005), sedangkan pengujian derajat deasetilasi dilakukan dengan metode titrasi asam basa (Czechowska-biskup et al. 2012). Nilai DD dirumuskan sebagai berikut:

$$
\mathrm{DD}(\%)=2,03 \frac{\mathrm{V} 2-\mathrm{V} 1}{m+0,0042 \mathrm{~V} 2-\mathrm{V} 1},
$$

dimana:

$\mathrm{m}=$ berat sampel kitosan (gr)

$\mathrm{V}_{1}=$ volume awal titrasi $(\mathrm{ml})$

$\mathrm{V}_{2}=$ volume akhir titrasi $(\mathrm{ml})$

\section{Sintesis Membran Kitosan}

Sintesis membran kitosan menggunakan metode inversi fasa (Phase Inversion) dengan penguapan pelarut pada suhu pengeringan $80^{\circ} \mathrm{C}$ (Cheng et al. 2010; DeCarlo et al. 2014). Membran kitosan dibuat dengan variasi rasio komposisi kitosan:PVA sebesar 40:60, 45:55, 50:50, 55:45 dan 60:40 (v/v) serta variasi pengadukan pada $200 \mathrm{rpm}$ dan $250 \mathrm{rpm}$. Membran kitosan dengan variasi rasio 40:60(v/v) dan kecepatan $200 \mathrm{rpm}$ dibuat dengan menambahkan 0,25 gram PEG pada campuran 40 $\mathrm{ml}$ kitosan 5\% (w/v) dan $60 \mathrm{ml}$ PVA 5\% $(\mathrm{w} / \mathrm{v})$ dalam pengadukan $200 \mathrm{rpm}$ hingga homogen. Larutan kemudian dituang pada cawan petri dan dikeringkan pada suhu $80{ }^{\circ} \mathrm{C}$ selama 24 jam untuk membentuk lapisan membran. Pelepasan membran dilakukan dengan perendaman $\mathrm{NaOH} 1 \%$ (b/v) selama dua jam. Membran kemudian dicuci menggunakan aquades hingga $\mathrm{pH}$ air pencuci netral, dipotong dengan ukuran diameter $4 \mathrm{~cm}$, dan disimpan dalam ren- 
daman aquades sebelum digunakan dalam aplikasi filtrasi.

\section{Analisis Kuat Tarik dan Morfologi Membran}

Karakterisasi membran meliputi uji ke kuatan mekanik dan morfologi membran. Analisis morfologi membran dan unsur kimia dalam membran sebelum dan setelah aplikasi filtrasi dilakukan dengan menggunakan scanning electron microscopy and energy dispersive $x$-ray (SEM-EDAX, SEM-INSPECT 150 EDAX-Amatex Genesis Apex 2) (Tomás-Alonso et al. 2013). Pengujian SEM-EDAX dilakukan di Laboratorium Divisi Karakterisasi Material-Jurusan Material dan Metalurgi, Institut Teknologi Sepuluh November Surabaya. Pengujian kekuatan mekanik membran dilakukan dengan uji tarik yang dilakukan pada suhu ruang dengan menggunakan alat Autograph AG-X TE Shimadzu. Pengujian kuat tarik dilakukan di Laboratorium Dasar Bersama-Fakultas Farmasi, Universitas Airlangga.

\section{Aplikasi Filtrasi dengan Reaktor Crossflow dan Penentuan Nilai Fluks}

Aplikasi filtrasi limbah POME dilakukan dengan menggunakan sistem reaktor crossflow pada tekanan 3 bar dan filtrasi dilakukan selama 50 menit, dimana limbah POME diumpankan ke dalam reaktor dengan menggunakan boosterpump (Sari 2014). Permeabilitas membran dilakukan dengan pengujian fluks. Fluks membran ditentukan berdasarkan volume filtrat yang lolos melewati membran dengan diameter kontak 3 cm pada selang waktu 50 menit. Selektivitas membran dilakukan dengan pengujian rejeksi membran terhadap padatan (TSS dan TDS) dari limbah POME. Selektivitas membran ditentukan berdasarkan nilai padatan sebelum dan sesudah aplikasi filtrasi.

\section{Analisis TDS dan TSS}

Limbah POME yang digunakan dalam penelitian ini merupakan outlet cooling pond yang telah melalui proses pendinginan dan pengendapan awal. Pengukuran kandungan padatan (TDS dan TSS) dalam limbah sebelum dan setelah aplikasi filtrasi dilakukan dengan menggunakan metode gravimetric (APHA, AWWA, and WEF 2005). Nilai TSS dan TDS dihitung berdasarkan rumus berikut:

$$
\begin{aligned}
& \operatorname{TSS}\left(\frac{m g}{L}\right)=\frac{(\mathrm{c}-\mathrm{a}-\mathrm{b})}{\text { vol. sampel }} \times 1000 \times 1000, \\
& \operatorname{TDS}\left(\frac{m g}{L}\right)=\frac{(\mathrm{d}-\mathrm{a})}{\text { vol.sampel }} \times 1000 \times 1000,
\end{aligned}
$$

dimana:

$$
\begin{aligned}
\mathrm{a}= & \text { berat cawan porselin awal } \\
\mathrm{b}= & \text { berat kertas saring awal } \\
\mathrm{c}= & \text { berat residu, kertas saring dan } \\
& \text { porselen setelah pemanasan } 105 \\
& { }^{\circ} \mathrm{C} \\
\mathrm{d}= & \text { berat filtrat dan porselen setelah } \\
& \text { pemanasan } 105^{\circ} \mathrm{C}
\end{aligned}
$$

\section{Analisis Statistik}

Data dalam penelitian disajikan dalam bentuk rata-rata dan dianalisis menggunakan two way analysis of variance (ANOVA) yang diujikan pada program SPSS16. Analisa dilakukan dengan menggunakan dua faktor (rasio komposisi membran dan kecepatan pengadukan) dengan taraf kepercayaan \% $(0,05)$. 


\section{HASIL DAN PEMBAHASAN}

\section{Karakterisasi Kitosan}

Dalam penelitian, kitosan yang telah berhasil dibuat memiliki rendemen sebesar $8,72 \%(b / b)$. Hasil rendemen dari limbah rajungan ini lebih tinggi dibandingkan penelitian sebelumnya, yaitu sebesar $4,65 \%$ (Bolat et al. 2010).

Tabel 1. Karakterisasi kitosan dari rajungan

\begin{tabular}{lll}
\hline Parameter & Hasil analisis & Baku mutu* \\
\hline Warna & $\begin{array}{l}\text { putih kecoklatan } \\
\text { tidak berbau }\end{array}$ & $\begin{array}{l}\text { putih } \\
\text { tidak berbau }\end{array}$ \\
Bau & Larut & \\
Kelarutan & $9.62 \%$ & $<10 \%$ \\
Kadar air & $0.37 \%$ & $<2 \%$ \\
Kadar abu & $93.51 \%$ & $>70 \%$ \\
Derajat Deasetilasi & 200-799 cps \\
$\begin{array}{l}\text { Viskositas (larutan } \\
\text { kitosan 5\%) }\end{array}$ & $262.23 \mathrm{cps}$ & (medium) \\
\hline $\begin{array}{l}\text { Sumber (PROTAN laboratories 1987) } \\
\end{array}$ &
\end{tabular}

Hasil karakterisasi kitosan diketahui telah memenuhi baku mutu sehingga kitosan yang telah dibuat layak untuk dijadikan bahan baku membran kitosan (Tabel 1). Derajat deasetilasi merupakan parameter penting dalam kualitas kitosan. Derajat deasetilasi menunjukkan persentase gugus asetil yang dapat dihilangkan dari kitin sehingga dihasilkan kitosan. Derajat deasetilasi yang tinggi menunjukkan rendahnya gugus asetil yang masih terkandung dalam kitosan. Semakin sedikit gugus asetil pada kitosan, maka interaksi antar ion dan ikatan hidrogen dari kitosan akan semakin kuat (Patria 2013).

\section{Kandungan Awal Padatan POME}

Karakterisasi kandungan padatan awal limbah sebelum aplikasi filtrasi dilakukan pada suhu limbah $30^{\circ} \mathrm{C}$.
Tabel 2. Karakteristik awal POME

\begin{tabular}{lccc}
\hline \multirow{2}{*}{ Parameter } & Satuan & \multicolumn{2}{c}{ Karakteristik } \\
\cline { 3 - 4 } & & Hasil Analisis & $\begin{array}{l}\text { Baku } \\
\text { Mutu }\end{array}$ \\
\hline Suhu & o C & 30 & $30^{*}$ \\
$\mathrm{pH}$ & & 4.8 & $6-9^{*}$ \\
TSS & $\mathrm{mg} / \mathrm{l}$ & $19.000-20.000$ & $250^{*}$ \\
TDS & $\mathrm{mg} / \mathrm{l}$ & $7.000-10.000$ & $1000^{* *}$ \\
${ }^{*}$ sumber & (Peraturan & Menteri Lingkungan Hidup \\
2014) & & & \\
${ }^{* *}$ Sumber (PeraturanPemerintah 2001) &
\end{tabular}

Secara fisik, limbah POME berwarna coklat kehitaman, berbau menyengat, berminyak dengan suhu $\pm 31{ }^{\circ} \mathrm{C}$. Bau menyengat dan warna hitam pada POME disebabkan tingginya kandungan bahan organik yang terdekomposisi dan teroksidasi oleh mikroba yang terkandung dalam POME. Dari hasil analisis pada Tabel 2, karakteristik POME (TSS dan TDS) masih jauh dari standar baku mutu limbah cair PKS yang berlaku, sehingga diperlukan sistem pengolahan yang baik dalam penurunan nilai padatan limbah POME. Tingginya kandungan TDS dan TSS limbah POME dikarenakan serat halus buah yang lolos pada proses penyaringan dan terikut dalam aliran limbah yang berupa padatan halus tersuspensi.

\section{Pengaruh Rasio Komposisi Membran dan Kecepatan Pengadukan terhadap Kekuatan Mekanik Membran}

Berdasarkan Tabel 3, dapat dilihat bahwa kecepatan pengadukan memberikan pengaruh signifikan pada kuat tarik membran $(\alpha=0.013)$. Kuat tarik membran pada kecepatan pengadukan $250 \mathrm{rpm}$ lebih besar dibandingkan dengan kecepatan $200 \mathrm{rpm}$. Hal ini disebabkan karena pada kecepatan pengadukan $250 \mathrm{rpm}$, ikatan dan reaksi penggabungan antara kitosan, PVA, dan PEG terjadi lebih sempurna. Pengadukan menjadikan partikel-partikel zat bergerak 
dan bersentuhan dengan partikel lainnya sehingga reaksi dapat berjalan dengan lebih cepat dan sempurna. Selain itu, pemberian PEG juga berfungsi untuk meningkatkan elastisitas membran, sehingga meningkatkan kuat tarik membran (Croisier and Jérôme 2013).

Tabel 3. Nilai kuat tarik membran pada variasi rasio membran dan kecepatan pengadukan

\begin{tabular}{cccc}
\hline \multirow{2}{*}{$\begin{array}{c}\text { Rasio } \\
\text { kitosan:PVA }\end{array}$} & $\begin{array}{c}\text { Konsentrasi } \\
\text { kitosan } \\
(\%, \mathrm{v} / \mathrm{v})\end{array}$ & \begin{tabular}{c} 
Kuat \\
\cline { 3 - 4 }
\end{tabular} & $\begin{array}{c}\text { Tarik Membran } \\
\left(\mathrm{kgf} / \mathrm{cm}^{2}\right)\end{array}$ \\
\hline $40: 60$ & 40 & 0.74 & 0.78 \\
$45: 55$ & 45 & 0.86 & 1.25 \\
$50: 50$ & 50 & 1.05 & 1.37 \\
$55: 45$ & 55 & $1.19^{*}$ & $1.64^{*}$ \\
$60: 40$ & 60 & 1.05 & 1.47 \\
\hline
\end{tabular}

Keterangan: *beda nyata, $\alpha<0,05$

Berdasarkan Tabel 3, baik pada pengadukan $200 \mathrm{rpm}$ maupun $250 \mathrm{rpm}$, dapat dilihat bahwa kekuatan membran meningkat dengan meningkatnya persentase kitosan dalam campuran dan mencapai titik optimal pada rasio 55:45 diikuti dengan penurunan kuat tarik pada peningkatan konsentrasi kitosan dalam campuran. Nilai kuat tarik membran terbesar didapatkan pada membran dengan rasio komposisi kitosan:PVA sebesar 55:45 pada kecepatan pengadukan 250 rpm. Hal tersebut didukung oleh penelitian sebelumnya yang menyatakan bahwa nilai kekuatan tarik pada saat putus meningkat dengan meningkatnya komposisi kitosan (Farha and Kusumawati 2012; Setiawan, Argo, and Hendrawan 2015). Semakin besar rasio kitosan yang ditambahkan dalam campuran membran, maka nilai kuat tariknya cenderung meningkat. Hal ini menunjukkan bahwa kitosan sebagai biopolimer cenderung meningkatkan kuat tarik pada formulasi tertentu sehingga membran menjadi lebih rapat.

Pada konsentrasi kitosan dari $40 \%$ s.d. $55 \%(\mathrm{v} / \mathrm{v})$ kuat tarik mengalami kenaikan dan mengalami penurunan pada rasio komposisi kitosan $60 \%$. Penurunan kuat tarik membran disebabkan karena pada rentang konsentrasi $55-60 \%$ komposisi membran didominasi oleh kitosan dan sedikit PVA sehingga kekuatan plastik membran berkurang (Farha and Kusumawati 2012). Struktur dan pori membran dipengaruhi oleh massa kitosan dalam campuran membran. Semakin besar konsentrasi kitosan hingga titik tertentu akan menghasilkan membran dengan struktur yang lebih baik, kemudian akan terjadi penumpukan kitosan pada membran dengan penambahan konsentrasi kitosan lebih lanjut dalam larutan (Rohman, Baroroh, and Utami 2009).

\section{Pengaruh Rasio Komposisi Membran dan Kecepatan Pengadukan terhadap Nilai Fluks}

Berdasarkan pada Gambar 1, semakin lama waktu pengoperasian maka semakin kecil fluks yang dihasilkan. Hal ini di akibatkan terjadinya fouling pada membran yang disebabkan oleh adanya adsorpsi polutan limbah ke permukaan dan dalam membran, sehingga partikel-partikel terakumulasi dan membentuk lapisan pada permukaan dan pori dalam membran yang menyebabkan penyempitan pada pori yang berakibat menurunnya nilai fluks membran (Nasir, Budi, and Silviaty 2013). Hal ini juga didukung oleh analisis SEM-EDX (Gambar 2).

Berdasarkan analisis SEM-EDX, komposisi unsur membran sebelum membran digunakan untuk mengolah limbah POME mengandung unsur $\mathrm{C}$ dan $\mathrm{O}$. Unsur-unsur tersebut berasal dari bahan utama pem buatan membran dan bahan pendukung membran. Bahan utama pembuatan membran adalah kitosan yang mengandung unsur $\mathrm{C}, \mathrm{H}, \mathrm{N}$, dan $\mathrm{O}$ dan bahan pendukungnya, yaitu Poly (vynil) Alcohol dan Poly (ethylene) Glycol yang mengandung unsur 
C, $\mathrm{H}$ dan O. Setelah aplikasi filtrasi di dalam membran terdapat unsur-unsur lain, yaitu $\mathrm{Mg}, \mathrm{Al}, \mathrm{Si}, \mathrm{P}, \mathrm{S}, \mathrm{Cl}, \mathrm{K}, \mathrm{Ca}$, dan $\mathrm{Fe}$. Unsur-unsur tersebut berasal dari polutan limbah POME yang tidak lolos dan terjebak dalam pori membran.

Fouling membran terjadi pada menit ke 150 yang ditandai dari nilai fluks yang cenderung konstan hingga menit ke 210 (Gambar 1). Nilai fluks membran pada pe- ngadukan $250 \mathrm{rpm}$ lebih kecil dibandingkan kecepatan $100 \mathrm{rpm}$. Nilai fluks membran dengan rasio komposisi kitosan dari 40\%$50 \%$ cenderung mengalami penurunan dan pada komposisi 50\%-60\% mengalami kenaikan. Penurunan nilai fluks menunjukkan bahwa pada konsentrasi kitosan 40\%-50\%, pori membran berada pada titik maksimum pembentukan pori membran, sedangkan penambahan konsentrasi kitosan dari $50 \%$

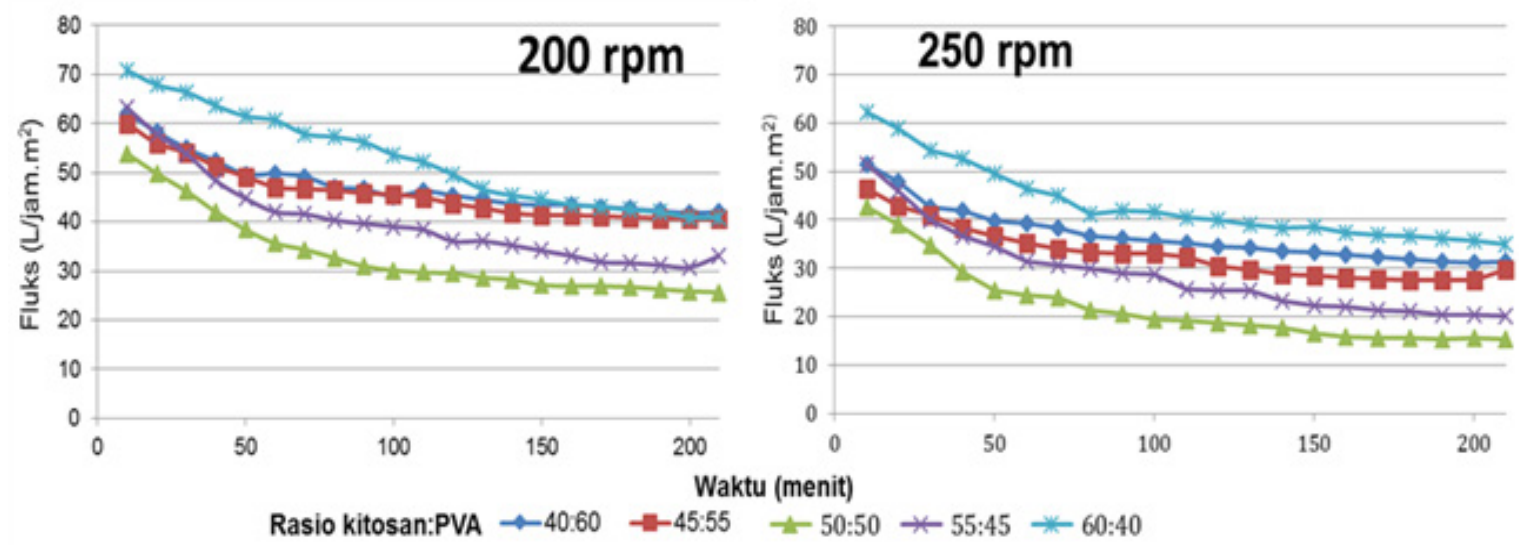

Gambar 1. Pengaruh rasio komposisi membran dan kecepatan pengadukan terhadap nilai fluks membran
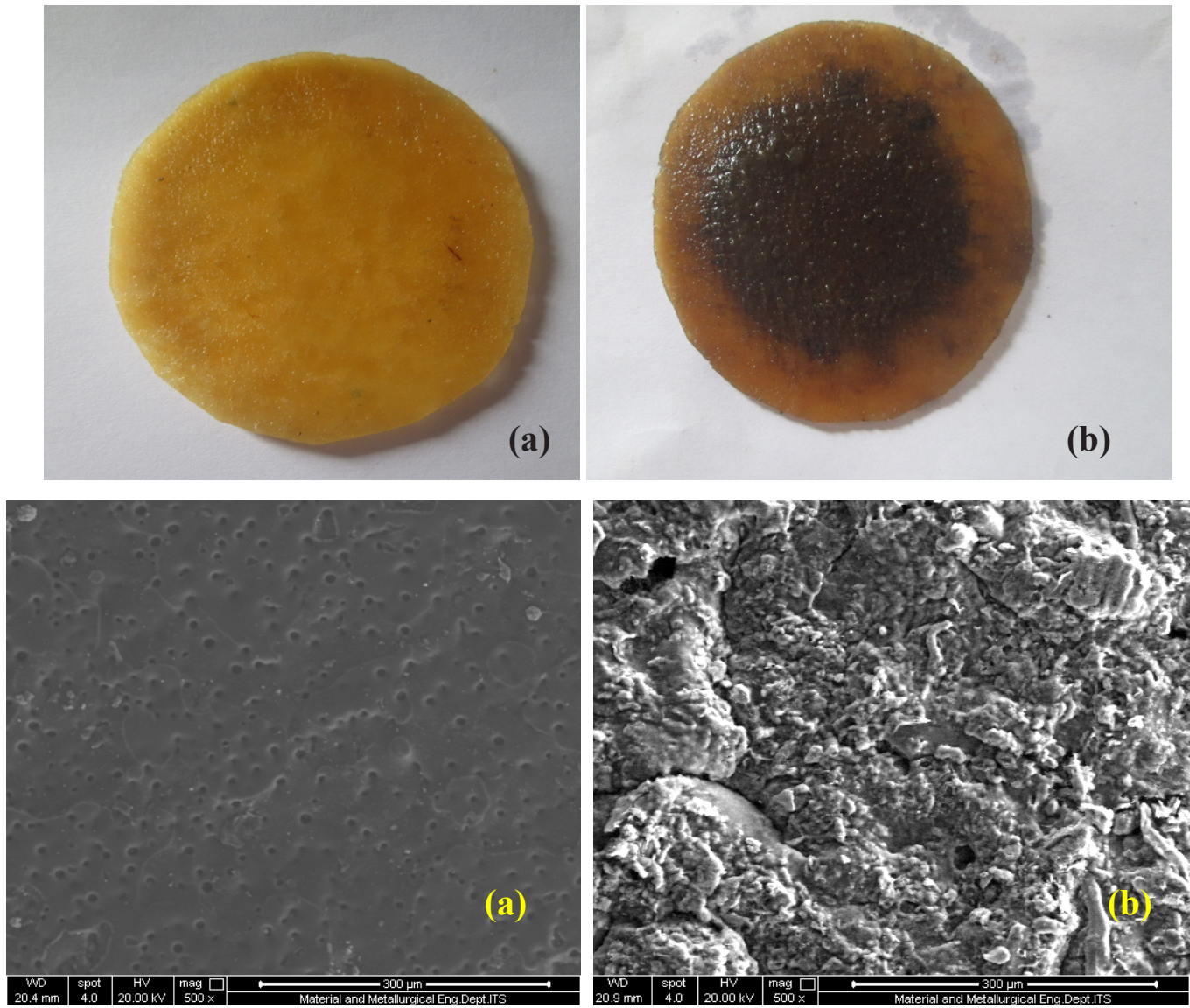

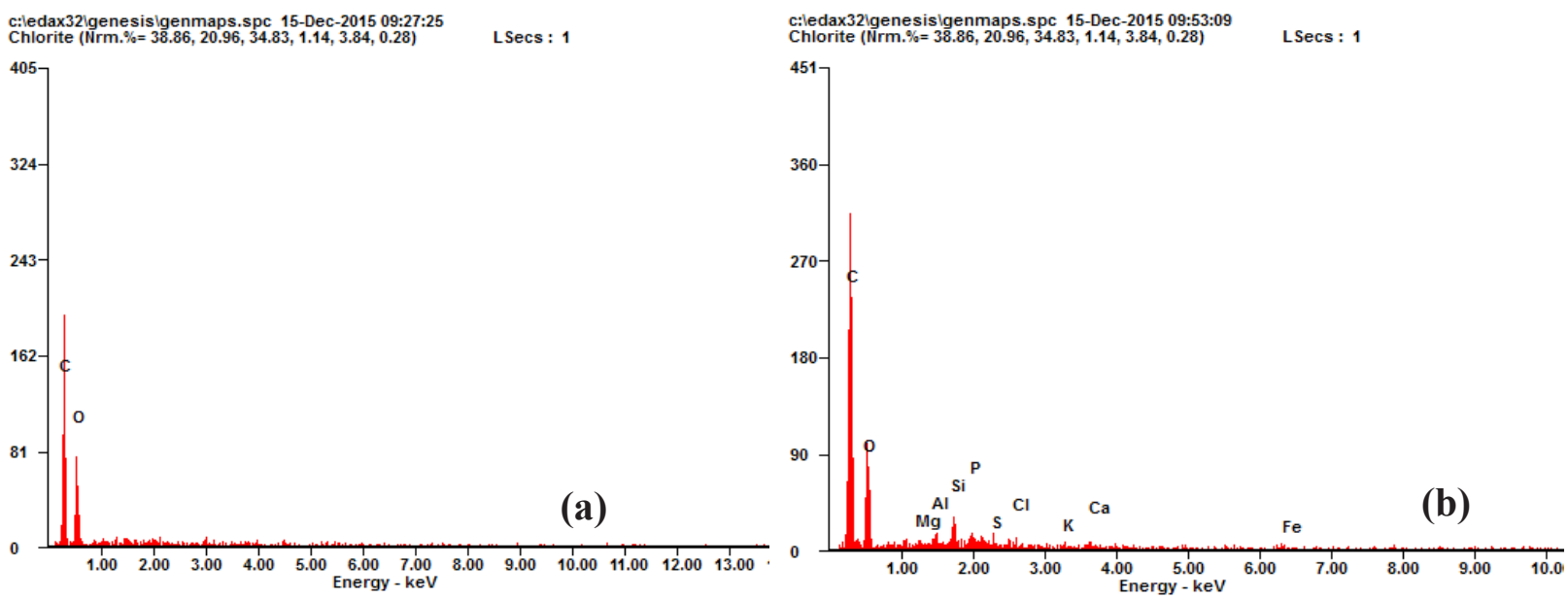

Gambar 2. Penampakan morfologi dan komposisi unsur membran (rasio 50:50 (v:v) dan kecepatan 250 rpm) yang dianalisis dengan SEM-EDX pada pembesaran 500x sebelum filtrasi (a) dan setelah filtrasi 150 menit (b)

menuju 60\% akan memperbesar pembentukan pori. Hal ini dikarenakan kandungan PVA sebagai matrik dalam membran tidak dapat mengimbangi kelebihan kandungan kitosan, sehingga kelebihan kitosan tersebut mendominasi sifat membran pori.

\section{Pengaruh Rasio Komposisi Membran dan Kecepatan Pengadukan terhadap Nilai Rejeksi TDS dan TSS}

Berdasarkan hasil pengujian dan perhitungan, dengan nilai TSS dan TDS awal sebesar 19.000-21.000 mg/L dan 7.000-10.000 $\mathrm{mg} / \mathrm{L}$, didapatkan nilai rejeksi TSS untuk masing-masing variasi yang ditunjukkan pada Tabel 4 dan Tabel 5.

Tabel 4. Nilai penurunan TSS pada variasi rasio membran dan kecepatan pengadukan

\begin{tabular}{ccc}
\hline \multirow{2}{*}{$\begin{array}{c}\text { Rasio } \\
\text { kitosan:PVA }\end{array}$} & \multicolumn{2}{c}{ Nilai penurunan TSS (\%) } \\
\cline { 2 - 3 } & $200 \mathrm{rpm}$ & $250 \mathrm{rpm}$ \\
\hline $40: 60$ & 87,39 & 89,72 \\
$45: 55$ & 89,72 & 92,49 \\
$50: 50$ & $92,19 *$ & $96,84^{*}$ \\
$55: 45$ & 91,17 & 92,89 \\
$60: 40$ & 88,41 & 89,33 \\
\hline
\end{tabular}

Keterangan: *beda nyata, $\alpha<0,05$
Tabel 5. Nilai penurunan TDS pada variasi rasio membran dan kecepatan pengadukan

\begin{tabular}{ccc}
\hline \multirow{2}{*}{$\begin{array}{c}\text { Rasio } \\
\text { kitosan:PVA }\end{array}$} & \multicolumn{2}{c}{ Nilai penurunan TDS (\%) } \\
\cline { 2 - 3 } & $200 \mathrm{rpm}$ & $250 \mathrm{rpm}$ \\
\hline $40: 60$ & 88,84 & 92,49 \\
$45: 55$ & 90,59 & 93,68 \\
$50: 50$ & $92,92 *$ & $97,23 *$ \\
$55: 45$ & 91,47 & 94,07 \\
$60: 40$ & 89,13 & 92,09 \\
\hline Keterangan: *beda nyata, $\alpha<0,05$ &
\end{tabular}

Berdasarkan pada Tabel 4 dan Tabel 5, rasio kitosan: PVA memberikan pengaruh signifikan pada nilai rejeksi TSS $(\alpha=0)$ maupun $\operatorname{TDS}(\alpha=0,005)$. Nilai rejeksi tertinggi dihasilkan oleh membran pada rasio kitosan dan PVA 50:50 (v:v) pada kecepatan pengadukan $250 \mathrm{rpm}$. Nilai rejeksi TDS dan TSS membran dengan rasio komposisi kitosan dari 40\%-50\% cenderung mengalami kenaikan dan pada komposisi 50\%-60\% mengalami penurunan. Hal ini berkaitan dengan pembentukan pori membran. Semakin kecil pori membran maka selektivitas membran akan semakin meningkat, sehingga nilai rejeksinya juga meningkat. Titik optimal komposisi kitosan dan PVA pada membran didapatkan pada komposisi 50:50 (v:v). Pada komposisi 
tersebut, kitosan sebagai adsorben dan absorben padatan bereaksi sempurna dengan PVA menghasilkan membran dengan pori terbaik sehingga menghasilkan nilai rejeksi yang tinggi. Pada konsentrasikitosan 55\% dan 60\% membran didominasi oleh kitosan dan sedikit PVA, sehingga kerapuhan kitosan mendominasi sifat membran.

Kecepatan pengadukan pada proses pembuatan membran memengaruhi nilai rejeksi TSS $(\alpha=0,012)$ dan TDS $(\alpha=0,025)$ membran. Kecepatan pengadukan $250 \mathrm{rpm}$ menghasilkan nilai rejeksi lebih tinggi dibandingkan dengan kecepatan pengadukan $200 \mathrm{rpm}$. Perbedaan nilai rejeksi ini disebabkan karena pada kecepatan tinggi, homogenisasi larutan, dan pembentukan pori lebih sempurna sehingga membentuk pori yang lebih rapat dibandingkan dengan pengadukan pada kecepatan rendah.

Berdasarkan Gambar 1, Tabel 4, dan Tabel 5, nilai fluks berbanding terbalik dengan nilai rejeksi TSS dan TDS. Proses pemisahan padatan dengan menggunakan membran dengan peningkatan nilai rejeksi akan di ikuti dengan menurunnya fluks permeate. Nilai rejeksi TSS dan TDS yang tinggi berkaitan dengan ukuran pori. Semakin kecil dan sempit pori membran, maka akan lebih sulit untuk melewati pori membran sehingga meningkatkan nilai rejeksi membran (Sari 2014; Wahyuni 2016). Berdasarkan Tabel 4 dan 5, nilai rejeksi TDS lebih besar dibandingkan nilai rejeksi TSS, hal ini menunjukkan bahwa dissolved solid yang sulit dipisahkan dari limbah POME terbukti dapat dipisahkan secara baik dengan aplikasi filtrasi membran.

\section{KESIMPULAN}

Berdasarkan nilai kuat tarik, fluks, dan nilai rejeksi padatan (TDS dan TSS), membran paling optimal didapatkan pada rasio kitosan:PVA sebesar 50:50(v:v) dan kecepatan pengadukan $250 \mathrm{rpm}$. Persentase penurunan TSS dan TDS tertinggi adalah sebesar $96,84 \%$ dan $97,23 \%$.

\section{UCAPAN TERIMA KASIH}

Penulis mengucapkan terima kasih kepada Direktorat Pendidikan Tinggi, Kementerian Pendidikan dan Kebudayaan Republik Indonesia yang telah memberikan dukungan finansial melalui beasiswa Fresh Graduate tahun 2014-2016 serta seluruh pihak yang mendukung dan membantu penelitian dalam jurnal ini.

\section{DAFTAR ACUAN}

APHA, AWWA, and WEF. 2005. Standard Methods for the Examination of Water and Wastewater 21th Edition. Edited by Mary Ann Franson. American Public Health Association. 21sted. Washington DC: American Public Health Association.

Ariyaskul, A S, R Y M Huang, P L Douglas, $\mathrm{R}$ Pal, $\mathrm{X}$ Feng, $\mathrm{P}$ Chen, and $\mathrm{L}$ Liu. 2006. "Blended Chitosan and Polyvinyl Alcohol Membranes for the Pervaporation Dehydration of Isopropanol." Journal of Membrane Science 280: 815-23.

Asni, Nurul, M Arif Saadilah, and Djonaedi Saleh. 2014. "Optimasi Sintesis Kitosan dari Cangkang Kepiting sebagai Adsorben Logam Berat $\mathrm{Pb}(\mathrm{II})$." Jurnal Fisika dan Aplikasinya 15 (1): 18-25.

Bolat, Yildiz, Şengül Bilgin, Ali Günlü, Levent Izci, Seval Bahadir Koca, Soner Çetinkaya, and H. U. Koca. 2010. "Chitin-Chitosan Yield of Freshwater Crab (Potamon Potamios, Olivier 1804) Shell." Pakistan Veterinary Journal 30 (4): 227-31. 
Bolto, Brian, Thuy Tran, Manh Hoang, and Zongli Xie. 2009. "Progress in Polymer Science Crosslinked Poly ( Vinyl Alcohol ) Membranes." Progress in Polymer Science 34: 969-81.

Cheng, Zihong, Xiaoshuai Liu, Mei Han, and Wei Ma. 2010. "Adsorption Kinetic Character of Copper Ions onto a Modified Chitosan Transparent Thin Membrane from Aqueous Solution." Journal of Hazardous Materials 182. Elsevier B.V.: 408-15.

Croisier, Florence, and Christine Jérôme. 2013. "Chitosan-Based Biomaterials for Tissue Engineering." European Polymer Journal 49 (4): 780-92.

Czechowska-biskup, Renata, Diana Jarosińska, Bożena Rokita, Piotr Ulański, and Janusz M Rosiak. 2012. "Determination of Degree of Deacetylation of Chitosan - Comparision of Methods." Progress on Chemistry and Application of Chitin and Its Derivatives XVII: 5-20.

Dash, M., F. Chiellini, R. M. Ottenbrite, and E. Chiellini. 2011. "Chitosan - A Versatile Semi-Synthetic Polymer in Biomedical Applications." Progress in Polymer Science (Oxford) 36 (8): 981-1014.

DeCarlo, Arthur, Ellis, April, Dooley, Thomas, Belousova, and Maria. 2014. Composition, Preparation and Use of Dence Chitosan Membrane Materials. US 8, 735, 571 B2, issued 2014.

Erizal, Dian Pribadi Perkasa, Zuhelmi Aziz, and GS Sulistioso. 2013. "Modifikasi Fisiko Kimia Membran Komposit Kitosan Polivinil Alkohol Hasil Casting dengan Teknik Induksi Iradiasi Gamma." Indonesian Journal of Materials Science 14 (3): 166-72.

Farha, Indah F, and Nita Kusumawati. 2012. "Pembuatan Membran Komposit Kitosan-PVA dan Pemanfaatannya pada Pemisahan Limbah Pewarna Rhodamin B." UNESA Journal of Chemistry 1 (2): 31-38.
Hidayat. 2014a. "Sintesis Membran Kitosan - PEG (Polietilen Glikol) dan Aplikasinya Sebagai Adsorben Ion $\mathrm{Cr}^{6+}$ Dan Ion $\mathrm{Ni}^{2+}$ dalam Larutan." Skripsi, Jurusan Kimia Universitas Negeri Semarang.

Hidayat, Fikri. 2014b. "Penurunan Kandungan Zat Warna pada Limbah Songket Menggunakan Membran Komposit Berbasis Kitosan-PVA secara Ultrafiltrasi." Skripsi, Jurusan Teknik Kimia Politeknik Negeri Sriwijaya.

Hyder, M N, and P Chen. 2009. "Pervaporation Dehydration of Ethylene Glycol with Chitosan - Poly ( Vinyl Alcohol ) Blend Membranes : Effect of CS - PVA Blending Ratios." Journal of Membrane Science 340: 171-80.

Lusiana, Retno Ariadi, Dwi Siswanta, and Takashi Hayashita. 2013. "The Influence of PVA . Cl . Citric Acid/ Chitosan Membrane Hydrophicility." Indonesian Journal of Chemistry 13 (3): 262-70.

Mahatmanti, F Widhi, Nuryono, and Narsito. 2016. "Adsorption of Ca ( II ), $\mathrm{Mg}$ ( II ), Zn ( II ), and Cd ( II ) on Chitosan Membrane Blended with Rice Hull Ash Silica and Polyethylene Glycol." Indonesian Journal of Chemistry 16 (1): 45-52.

Mahatmanti, Nuryono, and Narsito. 2017. "Porous Chitosan-Silica-Polyethylene Glycol Membrane for Dynamic Adsorption of Binary Mixtures $\mathrm{Cu}(\mathrm{II})$ and $\mathrm{Zn}$ (II) Ions." International Journal of Materials, Mechanics and Manufacturing 5 (1): 20-23.

Nasir, Subriyer, Teguh Budi, and Idha Silviaty. 2013. "Aplikasi Filter Keramik Berbasis Tanah Liat Alam Dan Zeolit Pada Pengolahan Air Limbah Hasil Proses Laundry." Jurnal Bumi Lestari 13 (1): 45-51.

Patria, A. 2013. "Production and Characterization of Chitosan from Shrimp Shell Waste." International Journal of the Bioflux Society 6 (4): 339-44.

Peraturan Pemerintah. 2001. "Pengelolaan 
Kualitas Airdan Pengendalian PencemaranAir."PeraturanPemerintahRepublik Indonesia No 82. doi:10.1017/ CBO9781107415324.004.

PerMenLH. 2014. "Baku Mutu Air Limbah bagi Usaha dan/atau Kegiatan Industri Minyak Sawit, Jakarta 1815." PerMenLH No 518155 (1815).

PROTAN laboratories. 1987. Cation Polymer for Recovery Valuable by Products from Processing Waste. Washington USA: PROTAN Laboratories Inc.

Rahardjo, Nugro. 2005. "Permasalahan Teknis Instalasi Pengolahan Air Limbah Pabrik Minyak Kelapa Sawit." Jurnal Agribisnis Indonesia 1 (1): 43-51.

Riyanto, Bambang, Ruddy Suwandi, and Ikhwan Dimas Permana. 2010. "Karakteristik Composite Biofiber Textile Berbahan Dasar Kitosan dan Polivinilalkohol ( PVA ) Melalui Proses Pemintalan Basah." Jurnal Pengolahan Hasil Perikanan Indonesia 8 (1): 12-25.

Rohman, Taufiqur, Umi Baroroh, dan Lili Utami. 2009. "Pengaruh Konsentrasi Kitosan Terhadap Karakter Membran Kitosan." Jurnal Sains Dan Terapan Kimia 2 (1): 14-24.

Rupani, Parveen, MH Ibrahim, RP Songh, and N Esa. 2016. "Review of Current Palm Oil Mill Effluent (POME) Treatment Methods: Vermicomposting as a Sustainable Practice." World Applied Sciences Journal 10 (10): 1190-1201.

Salehi, E., and S. S. Madaeni. 2014. "Influence of Poly(ethylene Glycol) as Pore-Generator on Morphology and Performance of Chitosan/poly(vinyl Alcohol) Membrane Adsorbents." Applied Surface Science 288: 537-41.

Sari, Tika Kumala. 2014. "Pengolahan Limbah Laundry Menggunakan Membran Nanofiltrasi Zeolit Variasi Massa untuk Filtrasi Kekeruhan dan Fosfat." Skripsi Jurusan Teknik
Lingkungan, Institut Teknologi Sepuluh Nopember, Surabaya.

Setiawan, Dian Aris, Bambang Dwi Argo, dan Yusuf Hendrawan. 2015. "Pengaruh Konsentrasi dan Preparasi Membran terhadap Karakterisasi Membran Kitosan." Jurnal Keteknikan Pertanian Tropis Dan Biosistem 3 (1): 95-99.

Suseno, Natalia, Tokok Adiarto, dan S Atie. 2003. "Sintesis dan Optimasi Membran Selulosa Asetat pada Proses Mikrofiltrasi Bakteri." Unitas 11 (2): 29-45.

Tomás-Alonso, Francisca, Aurora M Rubio, Rodrigo Álvarez, and Joaquín A Ortuño. 2013. "Dynamic Potential Response and SEM-EDX Studies of Polymeric Inclusion Membranes Based on Ionic Liquids." Int. J. Electrochem. Sci 8: 4955-69.

Wahyuni, Sri. 2016. "Studi Pembuatan dan Penggunaan Membran Chitosan dalam Pengolahan Limbah POME(Palm Oil Mill Effluent)." Tesis Jurusan Teknik Lingkungan, Institut Teknologi Sepuluh Nopember, Surabaya.

Yu, Qian, Yanan Song, Xiaomei Shi, Chunye $\mathrm{Xu}$, and Yuezhen Bin. 2011. "Preparation and Properties of Chitosan Derivative / Poly ( Vinyl Alcohol ) Blend Film Crosslinked with Glutaraldehyde." Carbohydrate Polymers 84 (1). Elsevier Ltd.: 465-70.

Yunarsih, Ni Made, Imanuntun Manurung, dan Ketut Gede Dharma Putra. 2013. "Efektivitas Membran Khitosan dari Kulit Udang Galah (Macrobanchium Rosenbergii) untuk Menurunkan Fosfat dalam Air Limbah Laundry." Jurnal Cakra Kimia 1 (2): 25-32.

Zhu, Yuexin, Shanshan Xia, Gongping Liu, and Wanqin Jin. 2010. "Preparation of Ceramic-Supported Poly ( Vinyl Alcohol )- Chitosan Composite Membranes and Their Applications in Pervaporation Dehydration of Organic / Water Mixtures." Journal of Membrane Science 349: 341-48. 
Widyariset | Vol. 3 No. 1 (2017) Hlm. 35 - 46 